\title{
Polybrominated diphenyl ethers (PBDEs) and heavy metals in road dusts from a plastic waste recycling area in north China: implications for human health
}

\author{
Zhenwu Tang $^{1,2} \cdot$ Qifei Huang ${ }^{2} \cdot$ Yufei Yang ${ }^{2} \cdot$ Zhiqiang Nie $^{2} \cdot$ Jiali Cheng $^{3} \cdot$ \\ Jun Yang ${ }^{4}$ Yuwen Wang ${ }^{1} \cdot$ Miao Chai $^{1}$
}

Received: 11 June 2015 / Accepted: 21 August 2015 / Published online: 2 September 2015

(C) Springer-Verlag Berlin Heidelberg 2015

\begin{abstract}
Road dusts were collected from an area where intense mechanical recycling of plastic wastes occurs in Wen'an, north China. These dusts were investigated for polybrominated diphenyl ethers (PBDEs) and heavy metals contamination to assess the health risk related to these components. Decabromodiphenyl ether (BDE-209) and $\Sigma_{21} \mathrm{PBDE}$ concentrations in these dusts ranged from 2.67 to 10 , $424 \mathrm{ng} \mathrm{g}^{-1}$ and from 3.23 to $10,640 \mathrm{ng} \mathrm{g}^{-1}$, respectively. These PBDE concentrations were comparable to those observed in road dust from e-waste recycling areas but were 12 orders of magnitude higher than concentrations in outdoor or road dusts from other areas. This indicates that road dusts in the study area have high levels of PBDE pollution. BDE-209
\end{abstract}

Responsible editor: Ester Heath

Electronic supplementary material The online version of this article (doi:10.1007/s11356-015-5296-7) contains supplementary material, which is available to authorized users.

Qifei Huang

huangqf@craes.org.cn

Jiali Cheng

jlcheng77@163.com

1 MOE Key Laboratory of Regional Energy and Environmental Systems Optimization, Environmental Research Academy, North China Electric Power University, Beijing 102206, China

2 State Key Laboratory of Environmental Criteria and Risk Assessment, Chinese Research Academy of Environmental Sciences, Beijing 100012, China

3 National Institute for Nutrition and Health, Chinese Center for Disease Control and Prevention, Beijing 100021, China

4 Center for Environmental Remediation, Institute of Geographic Sciences and Natural Resources Research, Chinese Academy of Sciences, Beijing 100101, China was the predominant congener, accounting for $86.3 \%$ of the total PBDE content in dusts. Thus, commercial deca-BDE products were the dominant source. The average concentrations of $\mathrm{As}, \mathrm{Cd}, \mathrm{Cr}, \mathrm{Cu}, \mathrm{Hg}, \mathrm{Pb}, \mathrm{Sb}$, and $\mathrm{Zn}$ in these same dust samples were $10.1,0.495,112,54.7,0.150,71.8,10.6$, and $186 \mathrm{mg} \mathrm{kg}^{-1}$, respectively. The geoaccumulation index suggests that road dusts in this area are moderately to heavily polluted with $\mathrm{Cd}, \mathrm{Hg}$, and $\mathrm{Sb}$. This study shows that plastic waste processing is a major source of toxic pollutants in road dusts in this area. Although the health risk from exposure to dust PBDEs was low, levels of some heavy metals in this dust exceeded acceptable risk levels for children and are of great concern.

Keywords Polybrominated diphenyl ethers (PBDEs) · Heavy metals $\cdot$ Road dust $\cdot$ Plastic waste recycling $\cdot$ Health risks

\section{Introduction}

The amount of plastic waste generated by households and industries globally has grown rapidly in recent years (Thompson et al. 2009). For example, about 275 million metric tons of plastic waste was generated by 192 coastal countries worldwide in 2010 (Jambeck et al. 2015). Dealing with the substantial quantities of end-of-life plastics generated annually is a critical task worldwide because this waste degrades slowly and can lead to various environmental problems (Rochman et al. 2013; Faure et al. 2015; Ma et al. 2015). Widely used traditional landfill and incineration practices are becoming less desirable disposal methods for plastics because of their negative environmental impacts and waste of resources. Instead, recycling of plastic waste has become the primary policy for treating plastic waste, including primary recycling, mechanical recycling, chemical recycling, and 
energy recovery (Al-Salem et al. 2009; Lazarevic et al. 2010). Of these recycling options, mechanical recycling is most popular in many countries because it recovers plastic waste for reuse in manufacturing plastic products; it also has relatively low investment and simple technology requirements (AlSalem et al. 2009; Lazarevic et al. 2010).

Polybrominated diphenyl ethers (PBDEs) are a class of additive brominated flame retardants with three typical formulations, i.e., penta-, octa-, and deca-BDE mixtures (La Guardia et al. 2006). PBDEs have been used extensively in a number of plastic products, yielding high residual levels of PBDEs in many plastic wastes (Morf et al. 2005; Kajiwara et al. 2008; Chen et al. 2009; Lyu et al. 2015). Morf et al. (2005) analyzed plastics in electrical wastes and found average concentrations of deca- and octa-BDEs of 510 and $530 \mathrm{mg} \mathrm{kg}^{-1}$. Chen et al. (2009) determined maximum PBDE concentrations in hard plastic toys of $5344 \mathrm{mg} \mathrm{kg}^{-1}$. In May 2009, the Stockholm Convention classified penta- and octa-BDE commercial formulations as persistent organic pollutants because of their toxic effects. Both production and use of penta- and octa-BDEs have been banned for several years in the European Union and elsewhere (Labunska et al. 2013). Decabromodiphenyl ether (BDE-209) also exhibits toxic properties in animals and can be metabolized in the environment to form toxic lessbrominated PBDEs (La Guardia et al. 2007; Kajiwara et al. 2008; Labunska et al. 2013). Although its use was phased out in North America and Europe, deca-BDE is still being produced and used in many countries, including China (Ni et al. 2013).

Multiclass metals are also added to plastics as additives or fill material (Morf et al. 2007; Li et al. 2011). In particular, high levels of toxic metals are usually found in plastics from electrical waste. For example, $\mathrm{Cd}$ concentrations of up to $761 \mathrm{mg} \mathrm{kg}^{-1}$ and $\mathrm{Sb}$ concentrations from 1.7 to $21.7 \mathrm{mg} \mathrm{kg}^{-1}$ were recorded in metallized plastic wastes (Soares et al. 2005). Santos et al. (2011) reported 4$12 \mathrm{mg} \mathrm{kg}^{-1}$ of $\mathrm{Hg}$ in plastics from electrical and electronic wastes. Some metals are also used as catalysts during plastic synthesis, as well as decoration/coatings for plastic products, resulting in contamination of some plastic wastes by nonadditive metals (Cheng et al. 2010; Guney and Zagury 2012; Kotori et al. 2012).

During mechanical recycling of plastics, such hazardous chemicals can be released into the ambient environment, especially when crude recycling methods are used or there are limited pollution control measures (Tang et al. 2014; He et al. 2015). In recent years, mechanical recycling of plastic wastes using environmentally unfriendly and crude technologies has increased in developing countries (Pacheco et al. 2012; Huang et al. 2013; Yang and Buekens 2014). Our previous studies showed that high concentrations of PBDEs (Tang et al. 2014), Cd and Hg (Tang et al. 2015), are present in soils and sediments from a major plastic recycling area in north China. This constitutes a potential health risk to local inhabitants. To date, evaluation of environmental parameters in these recycling areas is limited.

Road dust is comprised of solid particles deposited on roads that act as a "reservoir" for accumulating short-term environmental materials from the surrounding areas. The particles commonly include materials worn off the pavement, vehicular-related deposition particles, particles from atmospheric deposition, plant matter, and materials produced by erosion of the adjacent soil (Tang et al. 2013). Among the various environmental media, dust has usually been reported to have relatively high levels of toxic pollutants (Leung et al. 2008, 2011; Tang et al. 2013; Xu et al. 2015). Many previous studies have shown that the concentrations of toxic chemicals in the human body are strongly associated with those in dust, suggesting that dust is a significant exposure pathway to toxic substances (Dixon et al. 2009; Watkins et al. 2011).

In the plastic recycling areas, the road dust likely consists of some weathered plastic particles containing or is contaminated with harmful chemicals, which were originated from the transportation of various plastic wastes and the crude recycling of plastic wastes. In these areas, road dust may receive a large number of pollutant inputs from the contaminated surface soils by wind (Tang et al. 2014, 2015). In addition, the atmospheric pollutant emissions from the thermal process of plastic recycling might result in the heavy contamination of road dusts. To our knowledge, no studies have characterized PBDEs and metals in road dusts from plastic waste recycling areas, where crude mechanical methods are used; thus, the health risks at these sites have not been evaluated. We selected a plastic waste recycling area in Wen'an, north China, as our case study site. We carried out a reconnaissance survey to investigate and characterize the levels and contamination patterns of PBDEs and heavy metals in dust from this recycling area. Using these data, we assessed the potential risks of exposure to these two types of pollutants in dusts. Our results contribute to an understanding of the pollution caused by mechanical plastic waste recycling and provide information useful for establishing risk management measures.

\section{Materials and methods}

\section{Study area}

Wen'an County, situated in the northeast region of the North China Plain, is about $120 \mathrm{~km}$ south of Beijing; it has a population of 460,000 and an area of $1028 \mathrm{~km}^{2}$. Wen'an has a subhumid warm temperate monsoon climate (Sun et al. 2014). The mean temperature of Wen'an is approximately $12{ }^{\circ} \mathrm{C}$, and its average annual precipitation is approximately $567 \mathrm{~mm}$ (Sun et al. 2014). The main soil type in the study area is brown soil (Liu et al. 2001). Plastic recycling has been 
carried out intensively in Wen'an for more than 30 years, as one of the largest centers for mechanical recycling of plastics in north China (Liu 2011; Tang et al. 2014). At peak times, there are approximately 100,000 people engaged in this industry in Wen'an (Xu et al. 2010). The recycled wastes include poly(acrylonitrile-butadiene styrene) (ABS), polystyrene, polyvinyl chloride, polyethylene, polypropylene, polyamide, polycarbonate, and others originating from both industrial and household wastes. Recycling operations consist of collection, separation, milling, washing, agglutination, extrusion, quenching, and granulation. These processes were previously performed using crude techniques on a small scale in family workshops within the residential districts. Most had no environmental control and did not treat their gaseous or wastewater emissions. Since late 2011, the crude recycling processes have ceased and have been prohibited by the local government. In the area, the legacy of these previous recycling techniques, including environmental contamination, is still of concern.

\section{Sample collection}

Sampling was carried out in December 2011. Twenty composite samples of dust were collected along Road S334 using a random sampling strategy to assess pollution along this road. Road S334 is the main route for waste input and recycling output in the area. Using a modification of the procedure of Tang et al. (2013), each sample was collected by gently sweeping an area about $3 \mathrm{~m}^{2}$ adjacent to the curb of the road (within $1 \mathrm{~m}$ ) with a clean iron dustpan and brush. These dust samples were transferred to clean ground-glass stoppered bottles. An additional 11 composite samples of dust were collected from pathways outside family-run workshops within the residential areas, where long-running recycling activities have occurred in Wen'an. Sampling locations are shown in Fig. 1.

Samples were air dried at room temperature, and coarse debris was removed. Samples were ground using a mortar and pestle, before being passed through a 150-mesh (about $100 \mu \mathrm{m})$ nylon sieve. Road dust was operationally defined in this study as those particles with diameters below $100 \mu \mathrm{m}$ because they are easily resuspended and have the higher environment and health risks than the coarser fractions (Charlesworth et al. 2011; Cao et al. 2014). This finer fraction was stored at $-20{ }^{\circ} \mathrm{C}$ until analysis, in order to alleviate the volatilization and degradation of PBDEs.

\section{Sample analysis}

Based on the PBDE congener patterns for commercial formulations (penta-, octa-, and deca-BDE mixtures) and homologue profiles in other media environments in this area $(\mathrm{La}$ Guardia et al. 2006; Tang et al. 2014), 21 PBDE congeners were selected to measure in this study. PBDE concentrations in the dust samples were determined from ultrasonically extracted solutions using a gas chromatography/mass spectrometry (GC/MS), which was a modification of the method recommended by USEPA (EPA 1614, Draft) and reported in our previous study (Tang et al. 2014). Each sample $(8.00 \mathrm{~g})$ was spiked with the surrogate standard ${ }^{13} \mathrm{C}$-labeled $\mathrm{PCB}-141$ and extracted with $30 \mathrm{~mL}$ of hexane/dichloromethane $(1: 1, v / v)$ in an ultrasonic bath. The extracts were cleaned and fractionated using neutral, acid, and alkaline multilayer silica gel columns (silica gel, particle size 100-200 mesh, Sinopharm Chemical Reagent Co., Ltd) eluted with $70 \mathrm{~mL}$ of a 1:1 $(v / v)$ mixture of hexane and dichloromethane. The extract was concentrated to $0.2 \mathrm{~mL}$, and ${ }^{13} \mathrm{C}$-labeled PCB-208 was added prior to GC/MS analysis.

The GC oven temperature program was $60^{\circ} \mathrm{C}$ for $0.75 \mathrm{~min}$, increasing at $10^{\circ} \mathrm{C} \mathrm{min}^{-1}$ to $240{ }^{\circ} \mathrm{C}$, and then at $20^{\circ} \mathrm{C} \mathrm{min}^{-1}$ to $290{ }^{\circ} \mathrm{C}$; it was held at this temperature for $10 \mathrm{~min}$. The injector temperature was $250^{\circ} \mathrm{C}$, and the helium mobile phase flow rate was $1.0 \mathrm{~mL} \mathrm{~min}{ }^{-1}$. For analysis, $1-\mu \mathrm{L}$ aliquots of samples were injected. The injector was used in the splitless mode for the less brominated PBDEs (BDE-28, BDE-47, BDE-66, BDE-85, BDE-99, BDE-100, BDE-138, BDE-153, BDE-154, BDE-183, and BDE-190) and the split mode for more heavily brominated PBDEs (BDE-196, BDE-197, BDE201, BDE-202, BDE-203, BDE-205, BDE-206, BDE-207, BDE-208, and BDE-209).

The target PBDE congeners were identified if the GC retention time and ion abundance ratio matched those for the authentic corresponding standard. The levels of PBDEs were quantitatively determined by the internal standard method using peak area of composite standard. Linearity was tested in the concentration range from 2.5 to $100 \mu \mathrm{g} \mathrm{L}^{-1}$ (less brominated PBDEs) and 25 to $1000 \mu \mathrm{g} \mathrm{L}^{-1}$ (more heavily brominated PBDEs), respectively, by injecting replicate standards at seven different concentration levels. Within our experiments, all target compounds fulfilled the linearity with $R^{2}$ higher than 0.994. Relative standard deviations (RSDs) for consecutive injections of standard solutions at different concentration levels ranged from 1.00 to $4.50 \%$. Recoveries were in the range of $81.5-127 \%$, depending on individual congeners. The limits of detection (LODs) were estimated based on a signal to noise ratio of 5. The LODs of BDE-203, BDE-206, and BDE-209 were 105,182 , and $227 \mathrm{pg} \mathrm{g}^{-1}$, respectively. Other congeners varied from 1.93 to $77.5 \mathrm{pg} \mathrm{g}^{-1}$. In this study, some samples were re-detected and concentrated to suitable concentrations to inject when their measured areas were beyond the range of calibration curve. Sample concentrations below LOQ were replaced with one half of the LOQ in statistical analysis (EFSA 2010; Zheng et al. 2015). Reported concentrations were not corrected for surrogate recovery in this study.

In the present study, eight heavy metals were selected as objective metal pollutants, which represent a broad category 


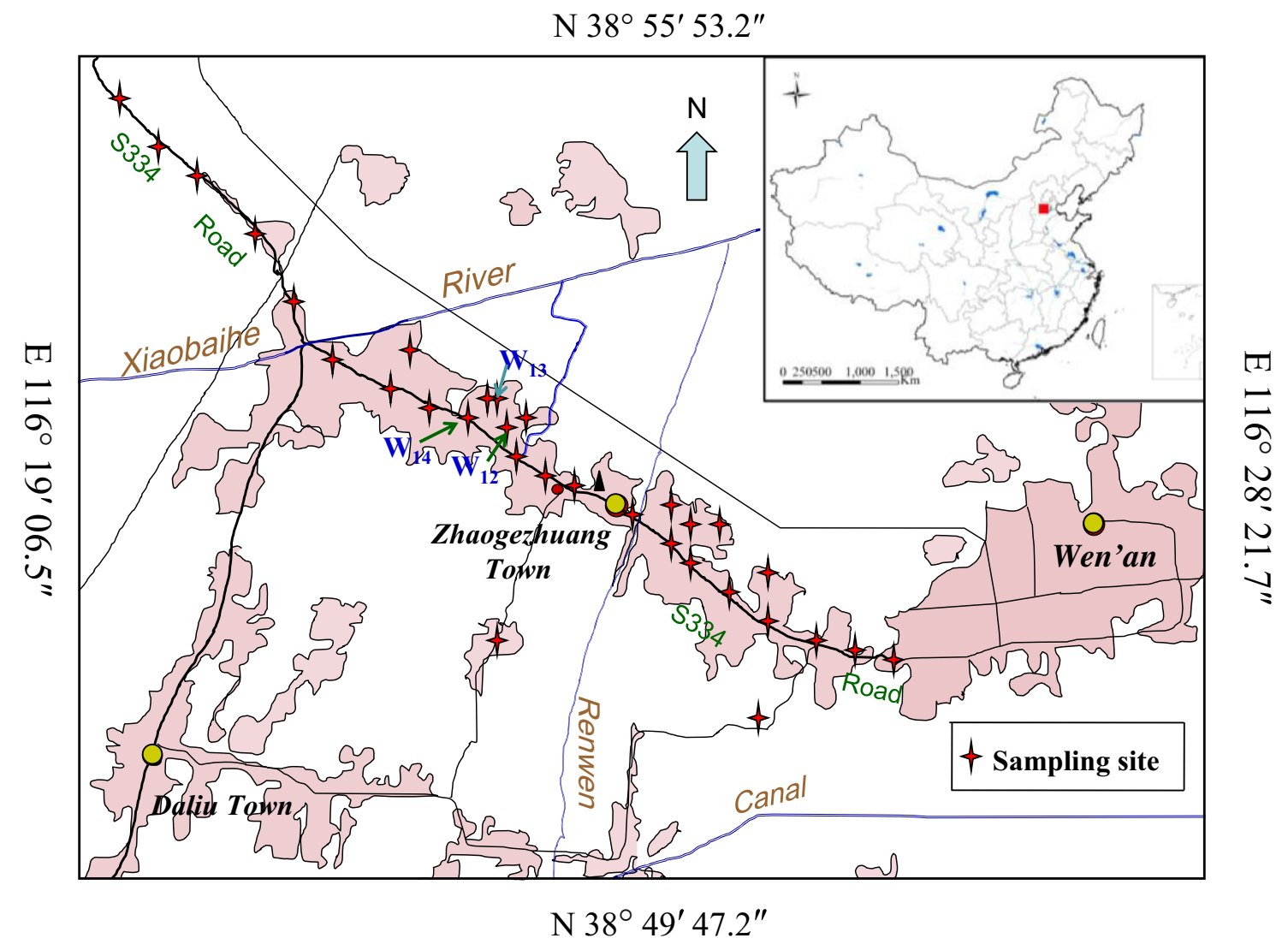

Fig. 1 Map of the road dust sampling sites in Wen'an, northern China

of chronic toxicity including mutagenicity, neurotoxicity developmental toxicity, and reproductive toxicity. Although As and $\mathrm{Sb}$ are strictly metalloids, we use a broad definition of "heavy metal," including these elements, to simplify the expressions in this manuscript. Metal concentrations of the samples were measured at the Institute of Geophysical and Geochemical Exploration, Chinese Academy of Geological Sciences, which is certified by the China National Accreditation Board for laboratories. The concentrations of $\mathrm{Cr}, \mathrm{Cu}, \mathrm{Zn}, \mathrm{Cd}, \mathrm{Sb}$, and $\mathrm{Pb}$ were determined using an inductively coupled plasma mass spectrometer (Thermo, Germany), while concentrations of $\mathrm{As}$ and $\mathrm{Hg}$ were measured using an atomic fluorescence spectrometer (XGY-1011A, China). Details of metal extraction and analysis are given in Yang et al. (2009). Briefly, about $0.25 \mathrm{~g}$ of dust was subjected to a digestion solution $\left(5.0 \mathrm{~mL} \mathrm{HNO}_{3}+10 \mathrm{~mL} \mathrm{HF}+2.0 \mathrm{~mL}\right.$ $\mathrm{HClO}_{4}$ ) and heated to evaporation at $200{ }^{\circ} \mathrm{C}$. After cooling, the residue was digested again in the same way and then mixed with $8-\mathrm{mL}$ aqua regia and heated until $2-3 \mathrm{~mL}$ of the mixture was left. The digested residue was brought up to a volume of $25 \mathrm{~mL}$ with deionized water. One milliliters of the diluted solution was taken and further diluted with $2 \%$ nitric acid to $10 \mathrm{~mL}$ for analysis.

Quality control was assured by the analysis of duplicate samples, a reagent blank, procedural blanks, and standard reference materials. Blanks were below the detection limit and repeat measurements of standards produced values within $\pm 10 \%$. Analytical precision of dust samples, expressed as relative standard deviation $(R S D)$, generally was better than $10 \%$. The detection limits were $2 \mu \mathrm{g} \mathrm{g}^{-1}$ for $\mathrm{Cr}, \mathrm{Pb}$, and $\mathrm{Zn}$, $1 \mu \mathrm{g} \mathrm{g}^{-1}$ for $\mathrm{Cu}, 0.2 \mu \mathrm{g} \mathrm{g}^{-1}$ for As, $0.05 \mu \mathrm{g} \mathrm{g}^{-1}$ for $\mathrm{Sb}$, $0.005 \mu \mathrm{g} \mathrm{g}^{-1}$ for $\mathrm{Hg}$, and $0.002 \mu \mathrm{g} \mathrm{g}{ }^{-1}$ for Cd. Soil sample GSS-17 and GSS-25 (geochemical standard reference sample soils in China) were analyzed to determine the accuracy of the procedure. The recovery of the total metals from the reference material was satisfactory and ranged between 95.4 and $117 \%$. Total organic carbon (TOC) content was determined using a Liqui TOC analyzer (Elementar, Germany).

\section{Metal pollution assessment}

The geoaccumulation index $\left(I_{\text {geo }}\right)$ was used to evaluate the pollution level of heavy metals in the dust samples. The $I_{\text {geo }}$, introduced by Muller in the late 1960s, has been widely used in trace metal studies (Muller 1969; Wei and Yang 2010). It can be calculated using $I_{\text {geo }}=\log _{2}\left(C_{\mathrm{n}} / 1.5 B_{\mathrm{n}}\right)$, where $C_{\mathrm{n}}$ is the measured concentration of a given metal in dust, $B_{\mathrm{n}}$ is the corresponding geochemical background value for this metal, and the coefficient 1.5 is used to amplify very small anthropogenic influences (Muller 1969). In this study, the soil 
background values for heavy metals in Hebei (CNEMC 1990), China, were selected for calculating the $I_{\text {geo }}$ values for our samples. The relationship between $I_{\text {geo }}$ values and pollution levels is defined as follows (Muller 1969): unpolluted $\left(I_{\text {geo }} \leq 0\right)$, unpolluted to moderately polluted $\left(0<I_{\text {geo }} \leq 1\right)$, moderately polluted $\left(1<I_{\text {geo }} \leq 2\right)$, moderately to heavily polluted $\left(2<I_{\text {geo }} \leq 3\right)$, heavily polluted $\left(3<I_{\text {geo }} \leq 4\right)$, heavily to extremely polluted $\left(4<I_{\mathrm{geo}} \leq 5\right)$, or extremely polluted $\left(I_{\mathrm{geo}}>5\right)$.

\section{Health risk assessment}

Children and adults are exposed to dust through three main pathways, i.e., ingestion of dust particles, inhalation of dust particles through the mouth and nose, and dermal contact with dust. The Exposure Factors Handbook (USEPA 2001) provides estimates of the average daily doses (ADDs) through ingestion, dermal contact, and inhalation for both adults and children. Thus, the human noncarcinogenic risk effects from heavy metals in dust can be assessed using the hazard quotient (HQ), which is the ratio of the ADD to the reference dose (RfD) of a given heavy metal for the same exposure pathway (USEPA 1989). If $\mathrm{HQ} \leq 1$, adverse health effects are unlikely to be experienced, whereas potential noncarcinogenic effects occur when HQ>1 (USEPA 1989; Leung et al. 2007). In this study, the inhalation RfD and dermal RfD of BDE-47, BDE99, BDE-153, BDE-209, penta-BDE, and octa-BDE were assumed to be equal to the ingestion RfD, because no reference values for the inhalation RfD and dermal RfD were available. Our estimation methods and values of the parameters used in our risk assessment are given in Tables S1 and S2, as well as in the Supplementary Material.

\section{Results and discussion}

\section{PBDE concentrations}

Descriptive statistics of PBDEs in our road dust samples are given in Table 1. PBDE congeners were detected at all sampling sites, indicating that these compounds are ubiquitous throughout the study area. BDE-209 and $\Sigma_{21}$ PBDE concentrations in the dust samples ranged from 2.67 to $10,424 \mathrm{ng} \mathrm{g}^{-1}$ and from 3.23 to $10,640 \mathrm{ng} \mathrm{g}^{-1}$, respectively. Individual PBDE congeners and the $\Sigma_{21}$ PBDEs had skewed concentration distributions, according to the Kolmogorov-Smirnov test $(p<0.05)$. Table 1 shows that the concentrations of PBDEs varied widely, having relatively high coefficients of variation. This suggests highly specific sources. In this study, there were no positive correlations between concentrations of TOC and most individual PBDE congeners or with $\Sigma_{21}$ PBDEs in the dust samples, except for BDE-209 $(p<0.05)$. Relatively high $\Sigma_{21}$ PBDE concentrations were found at sampling sites $\mathrm{W}_{12}$ (4456 $\left.\mathrm{ng} \mathrm{g}^{-1}\right), \mathrm{W}_{13}\left(10,640 \mathrm{ng} \mathrm{g}^{-1}\right)$, and $\mathrm{W}_{14}\left(7089 \mathrm{ng} \mathrm{g}^{-1}\right)$, collected near Yincun. Tang et al. (2014) also reported relatively high $\Sigma_{21} \mathrm{PBDE}$ concentrations presented at some soil samples which were collected in and near Yincun, the longestrunning continuous recycling site in Wen'an. Lowest levels of PBDEs were detected in samples collected from the roadsides in urban areas, which have been swept frequently.

So far, no environmental standards have been established for PBDEs in dusts. To evaluate the PBDE contamination status in the waste plastic recycling area at Wen'an, we compared our PBDE concentrations with those from previous work in other regions (Table S3). Based on PBDE relative potencies reported in the literature (Behnisch et al. 2003), toxic equivalent (TEQ) concentrations for selected indicative PBDE congeners were calculated from our measured dust PBDE concentrations. The $\Sigma_{21}$ PBDE and TEQ concentrations observed in this study were lower than concentrations reported in outdoor dusts from e-waste recycling regions in Wenling ( mean $=64.8 \mathrm{pg} \mathrm{TEQ} \mathrm{g}^{-1}$ ), Qingyuan (mean $=38.7 \mathrm{pg}$ TEQ $\mathrm{g}^{-1}$ ), and Taizhou (mean $=381$ pg TEQ $\mathrm{g}^{-1}$ ), China (Wang et al. 2010; Jiang et al. 2014; Xu et al. 2015). Typically, PBDE concentrations are much higher in e-wastes than in plastic wastes (Tang et al. 2014). PBDEs released by crude e-waste processing reflect the extremely destructive methods used to recover valuable materials from e-waste, such as acid washing and burning (Leung et al. 2007; Eguchi et al. 2013). However, BDE-209 and $\Sigma_{21}$ PBDE concentrations in the dusts in our study area were comparable to concentrations observed in road dusts from e-waste recycling sites (Wang et al. 2010; Leung et al. 2011). The level of PBDE contamination in road dusts in Wen'an was an order of magnitude higher than in Suzhou, Nantong, Wuxi, Shantou, and Wenling, China (Shi et al. 2014). Our results were 12 orders of magnitude higher than in regional outdoor dusts from Shantou and Shanghai (Leung et al. 2011; Wu et al. 2015). In addition, the BDE209, $\Sigma_{21}$ PBDE, and TEQ concentrations in the study road dusts were about double, respectively, those in the soils from this plastic recycling area (Tang et al. 2014). Compared with these results, road dust in the plastic recycling area in Wen'an had relatively high levels of PBDE pollution.

\section{Profile and source of PBDEs}

Compositions of PBDE congeners at different sampling sites are shown in Fig. 2. BDE-209 was the predominant congener in all road dust samples, accounting for 44.1-98.9 \% (mean= $86.3 \%$ ) of their $\Sigma_{21} \mathrm{PBDE}$ concentrations. This reflects the widespread use of commercial deca-BDE products in China, such as Saytex 102E and Bromkal 82-0DE (Xu et al. 2015). In addition, fugitive emissions from the disposal of PBDEcontaining plastic wastes could also contribute to BDE-209 in outdoor environments, because BDE-209 has a strong tendency to attach to soil particles. Tang et al. (2014) reported that BDE-209 was the dominant congener (representing 
Table 1 Summary of polybrominated diphenyl ether (PBDE) concentrations ( $\mathrm{ng} \mathrm{g}^{-1}$ dry wt), with basic statistical parameters, for the road dust collected from a waste plastic recycling area in Wen'an, northern China

\begin{tabular}{|c|c|c|c|c|}
\hline & $\mathrm{REP}^{\mathrm{a}}$ & Range & Mean \pm SD & CV/skewness \\
\hline BDE-28 & - & $0.001-1.52$ & $0.117 \pm 0.267$ & $2.27 / 5.13$ \\
\hline BDE-47 & $1.1 \times 10^{-6}$ & $0.0004-7.74$ & $0.806 \pm 1.49$ & $1.85 / 3.74$ \\
\hline BDE-66 & $2.0 \times 10^{-6}$ & $0.002-0.75$ & $0.121 \pm 0.149$ & $1.23 / 2.67$ \\
\hline BDE-85 & $2.1 \times 10^{-6}$ & $0.001-1.55$ & $0.117 \pm 0.290$ & $2.49 / 4.41$ \\
\hline BDE-99 & $5.6 \times 10^{-7}$ & $0.001-10.2$ & $0.836 \pm 1.92$ & $2.30 / 4.33$ \\
\hline BDE-100 & $1.2 \times 10^{-6}$ & $0.002-3.14$ & $0.311 \pm 0.627$ & $2.01 / 3.80$ \\
\hline BDE-138 & - & $0.002-8.35$ & $0.829 \pm 2.13$ & $2.57 / 2.93$ \\
\hline BDE-153 & $2.3 \times 10^{-6}$ & $0.002-101.4$ & $4.67 \pm 18.1$ & $3.87 / 5.47$ \\
\hline BDE-154 & - & $0.002-39.9$ & $2.82 \pm 7.52$ & $2.67 / 4.37$ \\
\hline BDE-183 & $1.5 \times 10^{-6}$ & $0.003-988$ & $40.3 \pm 177$ & $4.39 / 5.48$ \\
\hline BDE-190 & $4.6 \times 10^{-5}$ & $0.003-37.9$ & $2.12 \pm 7.16$ & $3.38 / 4.62$ \\
\hline BDE-196 & - & $0.008-61.9$ & $4.47 \pm 11.3$ & $2.53 / 4.72$ \\
\hline BDE-197 & - & $0.003-180$ & $8.72 \pm 32.2$ & $3.69 / 5.38$ \\
\hline BDE-201 & - & $0.007-12.3$ & $1.54 \pm 2.68$ & $1.74 / 2.97$ \\
\hline BDE-202 & - & $0.007-4.05$ & $0.479 \pm 0.803$ & $1.68 / 3.33$ \\
\hline BDE-203 & - & $0.053-75.7$ & $6.29 \pm 14.0$ & $2.23 / 4.36$ \\
\hline BDE-205 & - & $0.011-4.18$ & $0.417 \pm 1.03$ & $2.48 / 2.75$ \\
\hline BDE-206 & - & $0.091-103$ & $13.3 \pm 21.5$ & $1.62 / 2.96$ \\
\hline BDE-207 & - & $0.057-110$ & $9.95 \pm 20.8$ & $2.09 / 4.10$ \\
\hline BDE-208 & & $0.039-293$ & $12.8 \pm 52.2$ & $4.08 / 5.49$ \\
\hline BDE-209 & $1.6 \times 10^{-5}$ & $2.67-10424$ & $1430 \pm 2253$ & $1.58 / 2.73$ \\
\hline$\Sigma_{21}$ PBDEs & & $3.23-10640$ & $1541 \pm 2348$ & $1.52 / 2.56$ \\
\hline$\Sigma T E Q\left(p g\right.$ TEQ $\left.g^{-1}\right)$ & & $0.043-167$ & $23.1 \pm 36.1$ & $1.57 / 2.71$ \\
\hline
\end{tabular}

$S D$ standard deviation, $C V$ coefficient of variation

${ }^{a}$ Relative potencies (REPs), derived from a chemically activated luciferase gene expression (CALUX) cell bioassay $\left(\mathrm{EC}_{5 \mathrm{TCDD}}\right)$, were used to calculate the toxic equivalents (TEQs) (Behnisch et al. 2003). $\Sigma$ TEQ concentrations were calculated as the mean of the sum of BDE-47, BDE-66, BDE-85, BDE-99, BDE-100, BDE-153, BDE-183, BDE-190, and BDE-209
91.2 \% of the total PBDEs) in soils from the study area. BDE183 , one of the primary congeners found in octa-BDE products (La Guardia et al. 2006), had the second highest proportion, contributing on average $5.25 \%$ to the $\Sigma_{21} \mathrm{PBDE}$ concentrations in our dust samples. Similar results for outdoor or road dusts were reported elsewhere in China (Yu et al.
Fig. 2 Box plots of the relative abundances of different polybrominated diphenyl ether (PBDE) congeners in the dusts from Wen'an, northern China

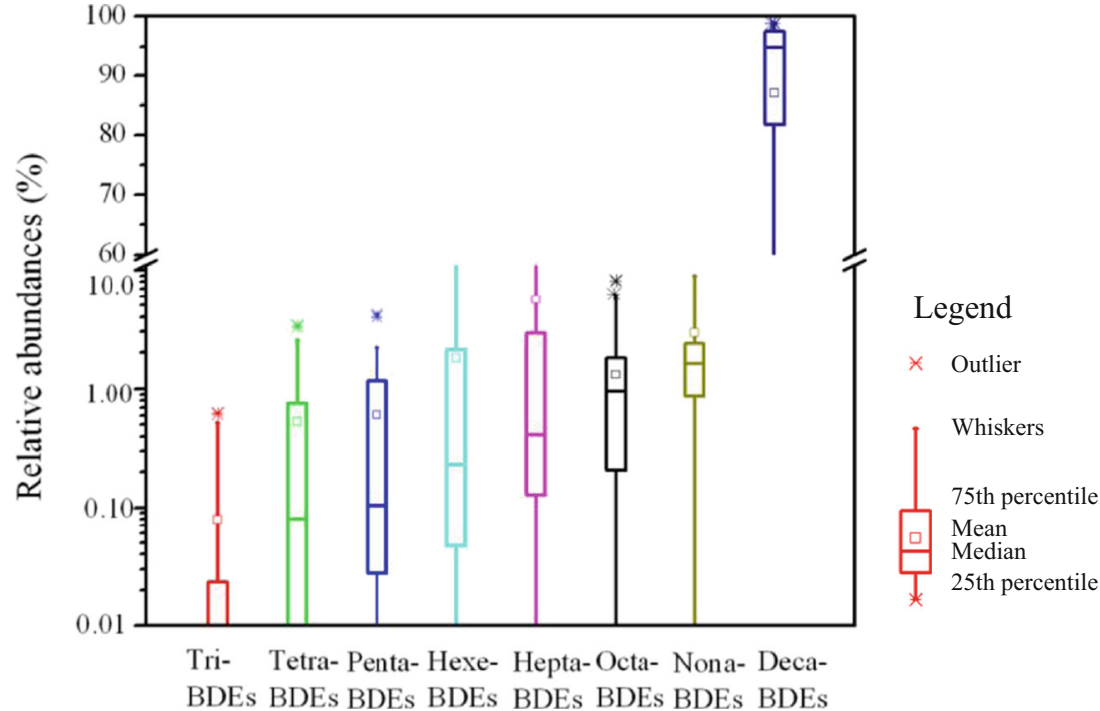


2012; Shi et al. 2014). Relatively high concentrations of the higher molecular weight PBDE congeners (BDE-206, BDE207, and BDE-208) were also found in our samples. The tri-, tetra-, and penta-BDE homolog groups each represented less than $1 \%$ of the $\Sigma_{21} \mathrm{PBDE}$ concentration, indicating that the congener patterns in dusts from the waste plastic recycling area were dominated by highly brominated PBDEs.

The congener profiles of PBDEs in our dust samples were different from those found in other studies. In some e-waste recycling areas in China, in addition to BDE-209 and BDE183 , BDE-47 and BDE-99 were clearly enriched in road dusts, reflecting the previous use of these commercial PBDEs in electronic products (Leung et al. 2011; Shi et al. 2014; Xu et al. 2015). Xu et al. (2015) reported that BDE-47 and BDE-99 contributed 24.4 and $26.5 \%$ to PBDE concentrations in outdoor dust samples from e-waste workshops in Taizhou. These differences in pollution patterns can be attributed to the different PBDEs used in electronics (e.g., printed circuit boards) compared with plastics (Leung et al. 2007). Furthermore, BDE-47 was the dominant congener, aside from BDE-209, in indoor dusts in many countries (Besis and Samara 2012). Thus, PBDE products used in China differ from other countries, contributing to a different congener profile.

Differences and similarities among the PBDE profiles of the dust samples were examined using principal component analysis (PCA) to evaluate source characteristics and subsequent environmental behaviors. Commercial penta-, octa-, and deca-BDE formulations (La Guardia et al. 2006) were explored as the major PBDE sources in the study area. Loading plots for individual congeners are given in Fig. 3. BDE-209 had a high negative loading for principal component 1 (PC1), indicating strong contributions from commercial deca-BDE formulations. BDE-47, BDE-85, BDE-99, BDE100 , BDE-153, and BDE-154 are major components of commercial penta-BDE mixtures, with high positive loadings in $\mathrm{PC} 1$. They are clustered in one group, confirming their similar origin from technical penta-BDE products. Principal component 2 (PC2) accounted for $22.9 \%$ of the total variance, predominated by BDE-183, BDE-196, BDE-197, BDE-201, BDE-203, BDE-206, and BDE-207, which are all major components of technical octa-BDE products, suggesting that their common source was octa-BDE products. Figure 3 shows that some octa- and nona-BDE congeners, such as BDE-202, BDE-205, BDE-206, and BDE-208, are separated from BDE-209 and BDE-183. These results signal that some degradation/transformation of higher molecular weight PBDEs has occurred. Deca-BDE in dusts is degraded under light to form nona-BDE or other species (Kajiwara et al. 2008). Likewise, deca-BDE is confirmed to undergo degradation under hydrothermal treatment to form lower brominated PBDEs (Nose et al. 2007). These highly brominated PBDEs may have been subject to degradation by the physical and chemical processes occurring during plastic manufacturing and/or waste plastic recycling.

Figure $\mathrm{S} 1$ shows a plot of $\mathrm{PC} 1$ versus $\mathrm{PC} 2$ scores calculated for each sample as well as for six commercial PBDE formulations. Most of the dust samples clustered with deca-BDE mixtures (Saytex 102E and Bromkal 82-0DE), indicating that deca-BDE products were the major PBDE source for dusts in the study area. In China, commercial deca-BDE mixtures account for most of the PBDEs used as flame retardants in plastics (Chen et al. 2012). Approximately $80 \%$ of the total decaBDE product produced in China is used in ABS and high impact polystyrene, as well as in polybutylene terephthalate and polyamide polymers (Chen et al. 2012). Because some dust samples (e.g., $\mathrm{W}_{6}, \mathrm{~W}_{10}, \mathrm{~W}_{8}$, and $\mathrm{W}_{9}$ ) had relatively high positive $\mathrm{PC} 1$ scores and were closely related to DE-71 and Bromkal 70-5DE, this indicates that penta-BDE formulations also influenced these samples.

\section{Contamination levels of metals}

Descriptive statistics for metal concentrations in the road dust samples from Wen'an are given in Table 2. Background soil values for Hebei as well as Chinese soil quality standards were used to evaluate metal contamination in our samples, because there is limited information for dust (CNEMC 1990; CEPA 1995). In our study area, $\mathrm{Cd}, \mathrm{Cu}, \mathrm{Hg}, \mathrm{Pb}, \mathrm{Sb}$, and $\mathrm{Zn}$ had nonnormal concentration distributions (KolmogorovSmirnov test, $p<0.05$ ), with relatively wide concentration ranges and high coefficients of variation. This suggests that heavy metal concentrations were strongly influenced by anthropogenic input. In the study, metal concentrations in the road dusts were generally comparable to concentrations observed in soils in this area (Tang et al. 2015). Aside from arsenic, the mean concentrations of all metals measured in our dust samples were higher than their background values in local soils. In particular, $\mathrm{Cd}, \mathrm{Hg}, \mathrm{Pb}$, and $\mathrm{Sb}$ were 5.27 , $4.18,3.34$, and 8.65 times their background values, respectively. In this plastic recycling area, $\mathrm{Cd}, \mathrm{Cr}, \mathrm{Cu}$, and $\mathrm{Pb}$ levels in dust samples surpassed their corresponding grade I guidelines for soil by 71.0, 90.3, 51.6, 61.3, and 29.2\%. In addition, approximately $54.8 \%$ of Cd samples exceeded their grade II guideline values.

A comparison of heavy metal concentrations in road dusts from Wen'an with those from other regions is given in Table S4. Compared with metal concentrations in street dusts from other Chinese cities, the road dusts from the plastic recycling area had relatively low to moderate levels of heavy metals. This suggests that higher levels of heavy metals are ubiquitous in urban dusts, as a result of a wide range of industrial and traffic sources (Lei et al. 2012; Lu et al. 2014). Concentrations of $\mathrm{As}, \mathrm{Zn}, \mathrm{Cd}$, and $\mathrm{Cu}$ in our road dusts also were relatively low compared with road dusts from e-waste recycling sites (Leung et al. 2008; Xu et al. 2015). In contrast, 
Fig. 3 Loading plots from the principal component analyses (PCA) for PBDEs in the dust samples collected from the waste plastic recycling area studied

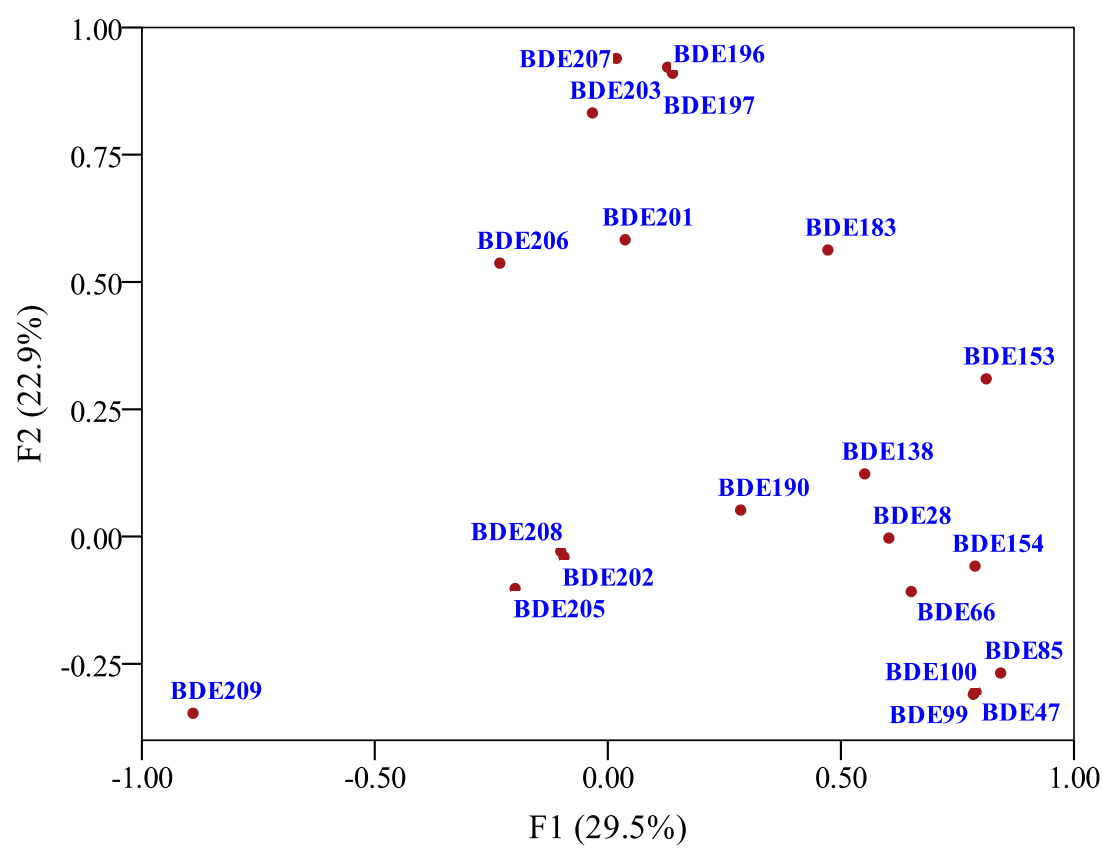

our $\mathrm{Cd}$ and $\mathrm{Pb}$ concentrations were comparable to those from the e-waste site at Wenling, China (Xu et al. 2015). Thus, moderate heavy metal pollution was recorded in the road dusts from the waste plastic recycling area.

To characterize the dust metal pollution, $I_{\text {geo }}$ values for heavy metals in dust samples were calculated (Fig. 4). The $I_{\text {geo }}$ values for $\mathrm{Cd}, \mathrm{Hg}, \mathrm{Pb}$, and $\mathrm{Sb}$ varied most, ranging from unpolluted to heavily or extremely polluted levels. This variability in road dust properties suggests different pollution sources for these metals. In the plastic recycling area, the $I_{\text {geo }}$ values exceeded 1.0 and 2.0 for $\mathrm{Cd}$ in 54.8 and $22.6 \%$ of samples, for $\mathrm{Hg}$ in 41.9 and $16.1 \%$ of samples, and for $\mathrm{Sb}$ in 32.3 and $19.4 \%$ of samples. This suggests that road dusts were moderately to heavily contaminated with $\mathrm{Cd}, \mathrm{Hg}$, and $\mathrm{Sb}$. Approximately one third of samples were moderately contaminated with $\mathrm{Pb}$. No geo-accumulation of other metals was observed.

\section{Source identification of metals}

PCA was used to identify the sources of heavy metal contamination in the road dusts. Results with a Kaiser-Meyer-Olkin Index $=0.823$ and Bartlett's sphericity tests at $p<0.001$ are shown in Fig. 5. The first two components explained $68.7 \%$ of the total variance in metal concentrations in the road dust samples. $\mathrm{PC} 1$ was dominated by $\mathrm{Cd}, \mathrm{Cu}, \mathrm{Sb}$, and $\mathrm{Zn}$, accounting for $53.2 \%$ of the total variance. As and $\mathrm{Hg}$ were highly loaded in $\mathrm{PC} 2$, which explained $15.5 \%$ of the total variance.

In the loading plot (Fig. 5), $\mathrm{Cd}, \mathrm{Cu}, \mathrm{Sb}$, and $\mathrm{Zn}$ formed a group with similar loading for both principal components,

Table 2 Heavy metal concentrations ( $\mathrm{mg} \mathrm{kg}^{-1}$ dry wt) of the road dust from the waste plastic recycling area

\begin{tabular}{|c|c|c|c|c|c|c|}
\hline & \multicolumn{3}{|c|}{ Concentration } & \multirow[t]{2}{*}{ Background values $^{\mathrm{a}}$} & \multirow[t]{2}{*}{ Chinese soil guidelines (grade I) ${ }^{\mathrm{b}}$} & \multirow[t]{2}{*}{ Chinese soil guidelines (grade II) ${ }^{\mathrm{b}}$} \\
\hline & Range & Mean $\pm \mathrm{SD}$ & CV/Skewness & & & \\
\hline As & $5.36-13.7$ & $10.1 \pm 1.96$ & $0.19 /-0.15$ & 13.6 & 15 & 30 \\
\hline $\mathrm{Cd}$ & $0.15-3.04$ & $0.50 \pm 0.60$ & $1.20 / 3.39$ & 0.094 & 0.2 & 0.3 \\
\hline $\mathrm{Cr}$ & $68.9-160$ & $112 \pm 22.1$ & $0.20 / 0.44$ & 68.3 & 90 & 200 \\
\hline $\mathrm{Cu}$ & $20.7-554$ & $54.7 \pm 93.9$ & $1.72 / 5.35$ & 21.8 & 35 & 100 \\
\hline $\mathrm{Hg}$ & $0.02-0.90$ & $0.15 \pm 0.19$ & $1.26 / 2.91$ & 0.036 & 0.15 & 0.50 \\
\hline $\mathrm{Pb}$ & $18.7-589$ & $71.8 \pm 106$ & $1.47 / 4.35$ & 21.5 & 35 & 300 \\
\hline $\mathrm{Sb}$ & $1.19-196$ & $10.6 \pm 34.9$ & $3.31 / 5.38$ & 1.22 & - & - \\
\hline $\mathrm{Zn}$ & $58.3-2025$ & $186 \pm 346$ & $1.86 / 5.34$ & 78.4 & 100 & 250 \\
\hline
\end{tabular}

$S D$ standard deviation, $C V$ coefficient of variation

${ }^{\text {a }}$ Soil background values for heavy metals in Hebei Province, China (CNEMC 1990)

${ }^{\mathrm{b}}$ Grade I/II guideline level for soil in China (GB 15618-1995) aims to protect the crop yield and public health (CEPA 1995) 
Fig. 4 Box plots of the geoaccumulation index for heavy metals in dusts from Wen'an, northern China. Contamination classes: unpolluted $\left(I_{\text {geo }} \leq 0\right)(I)$, unpolluted to moderately polluted $\left(0<I_{\text {geo }} \leq 1\right)(I I)$, moderately polluted $\left(1<I_{\text {geo }} \leq 2\right)(I I I)$, moderately to heavily polluted ( 2 $\left.<I_{\text {geo }} \leq 3\right)(I V)$, heavily polluted (3 $\left.<I_{\text {geo }} \leq 4\right)(V)$, heavily to extremely polluted $\left(4<I_{\text {geo }} \leq 5\right)$ $(V I)$, and extremely polluted $\left(I_{\text {geo }}>5\right)(V I I)$, using the method developed by Muller (1969)

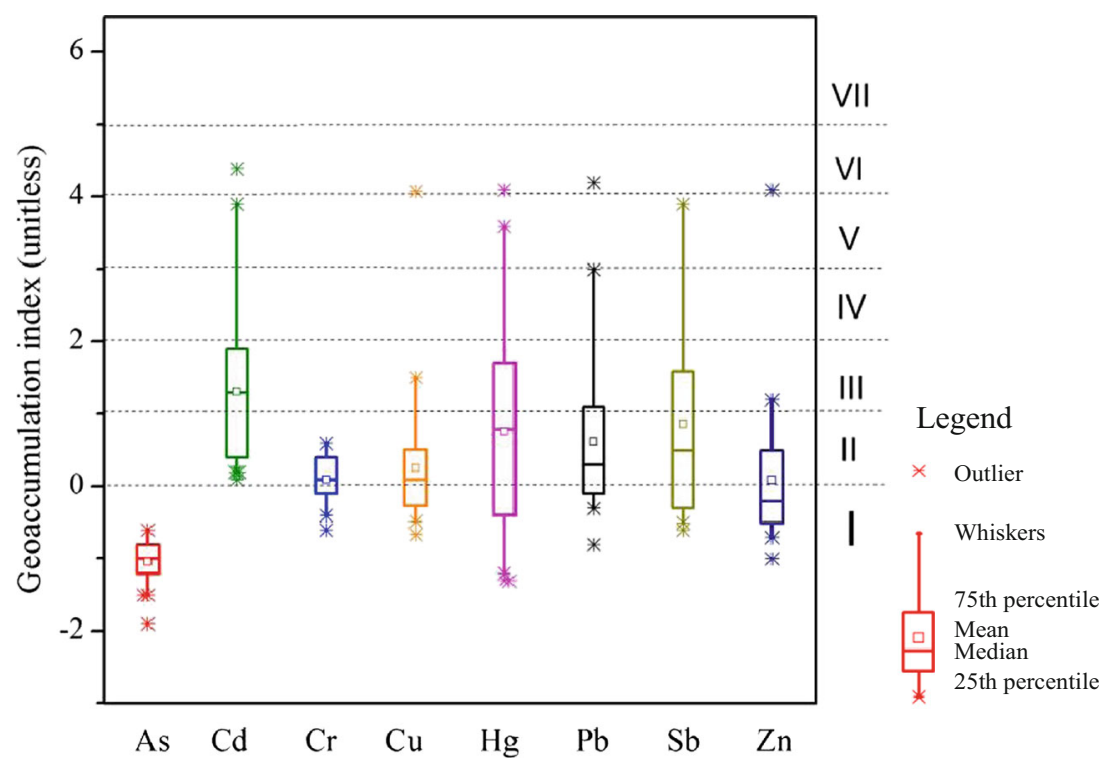

suggesting that these elements were from the same source. In plastics, various metals are used as additives or fill materials, including pigments (e.g., $\mathrm{ZnO}$ and $\mathrm{Cr}_{2} \mathrm{O}_{3}$ ), flame retardants $\left(\mathrm{Sb}_{2} \mathrm{O}_{3}\right)$, stabilizers, and plasticizers (e.g., compounds of $\mathrm{Cd}$ and $\mathrm{Zn}$ ). High heavy metal levels in plastic wastes have been reported in many previous studies (Soares et al. 2005; Santos et al. 2011). In addition, these four metals are positively correlated with each other at $p<0.01$ (Table S5). Concentrations of these four metals in most of the dust samples were higher than their soil background values. Thus, these four metals were mostly derived from plastic waste recycling. $\mathrm{Cr}$ also had a relatively high positive loading in $\mathrm{PC} 1$ and was positively correlated with $\mathrm{Cd}, \mathrm{Cu}, \mathrm{Sb}$, and $\mathrm{Zn}$, suggesting that the $\mathrm{Cr}$ pollution also was related to plastic recycling.
The $\mathrm{Pb}$ loading in the PCA was different from other metals, despite $\mathrm{Pb}$ being added to different plastic products as a stabilizer (Morf et al. 2007; Li et al. 2011). There were no significant correlations found between $\mathrm{Pb}$ and other metals, except for $\mathrm{Pb}$ and $\mathrm{Zn}$, indicating other sources for $\mathrm{Pb}$. Previous studies have found that accumulations of $\mathrm{Pb}$ in road dusts are attributed to the use of fossil fuels (Chen et al. 2010). However, given that leaded gasoline has been banned since 2000 in China, vehicle-exhaust emissions should contribute little to $\mathrm{Pb}$ pollution in road dusts (Cheng and $\mathrm{Hu} 2010$ ). Large coal consumption $\left(2.64 \times 10^{8} \mathrm{t}\right.$ in 2011$)$ and its associated industrial smoke discharge $\left(1.3 \times 10^{6} \mathrm{t}\right.$ in 2011) in Hebei suggest that coal combustion could be a major source of $\mathrm{Pb}$ pollution in road dusts in this area (CSB 2012).
Fig. 5 Loading plots of the principal component analysis (PCA) for metals in the road dust samples

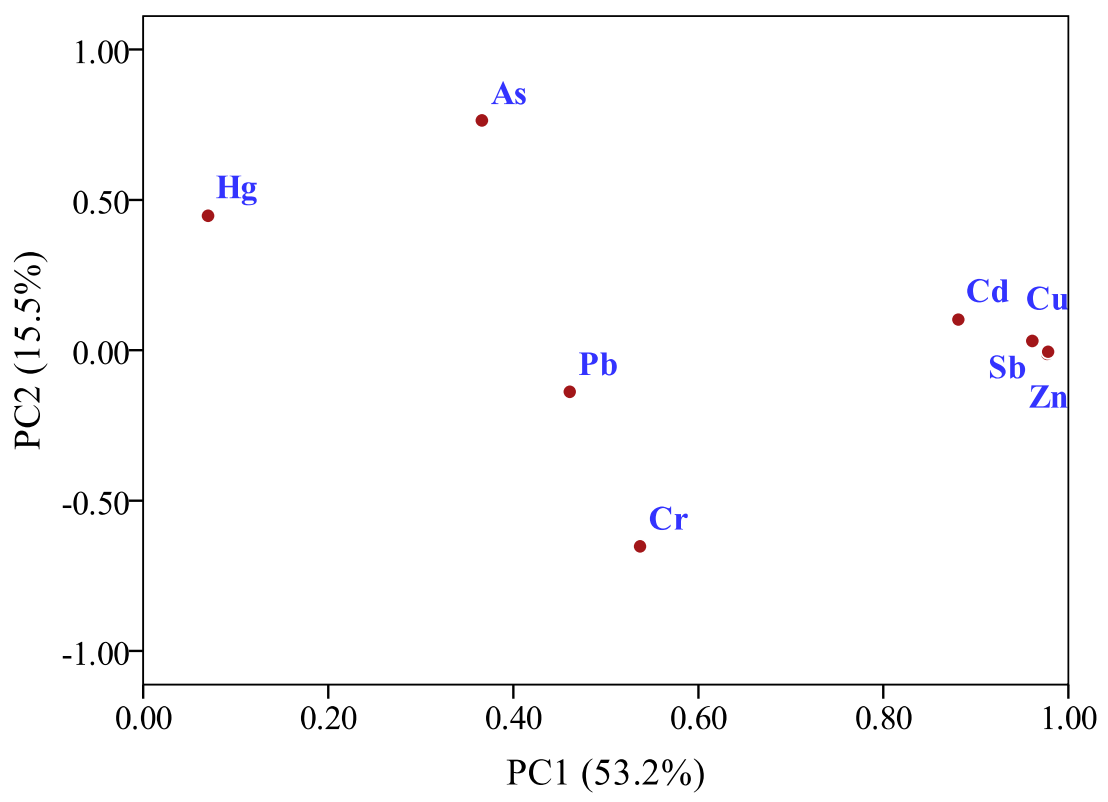


As and $\mathrm{Hg}$ had relatively high loadings in PC2. Almost all dust samples gave As concentrations comparable to the Hebei soil background values, indicating a natural source for As in samples. In Fig. 5, As and Hg are separated in the PCA loading plot, indicating that the two elements are poorly correlated. $\mathrm{Hg}$ loading (0.070) in PC1 was obviously lower than for other metals. Hg was not significantly correlated with any of the other metals, pointing to quasi-independent behavior of $\mathrm{Hg}$.

\section{Health risk assessment}

As part of a preliminary evaluation of human exposure to PBDEs in road dusts, the noncarcinogenic health risks to adults and children living in the vicinity of the plastic waste recycling area were calculated (Table 3). The exposures to BDE-47, BDE-99, BDE-153, BDE-209, penta-, octa-, decaBDE, and $\Sigma_{21}$ PBDEs via dust ingestion, inhalation, and dermal contact for both adults and children were several orders of magnitude lower than their corresponding RfD values. Thus, there is an overall low health risk for local PBDE exposure. However, the HQ for children for BDE-209 was 0.616 at the 95th percentile, indicating that potential noncarcinogenic risk for local children may deserve attention.

The HQs for metals for adults and children are shown in Table 3. The exposure HQs for adults for all eight metals was generally less than 1.0. HQs were higher than 1.0 in only a few dust samples, indicating no human health risks to adults in this area. For children, adverse health effects were predicted when using the 95th percentile concentrations for $\mathrm{Cd}, \mathrm{Pb}$, and $\mathrm{Sb}$, with HQs of $2.50,1.77$, and 11.5, respectively. The combined HQs for all eight heavy metals exceeded 1.0 for all road dust samples, indicating a high potential noncarcinogenic risk to local children within the plastic recycling area.

The model used in this investigation provides a useful tool for risk assessment, identifying health risks related to PBDEs and metals in local dusts. However, there are a number of inherent uncertainties. We did not consider the pollution variation over time nor the bioavailability of the pollutants in these dusts. Risks related to consumption of contaminated food and water that also contribute to ADDs were not taken into account. Last, the toxicity effect of PBDEs and metals are likely to be weakened or enhanced by other pollutants.

\section{Conclusions}

To the best of our knowledge, this is the first study on heavy metals and PBDEs in road dust from a plastic recycling area. This study shows that the crude mechanical recycling of plastic waste is a significant contributor of PBDEs and heavy metals to road dust. The levels of PBDEs in this study area were comparable with some e-waste recycling areas but much higher than those in the road dusts or outdoor dusts from other urban areas. This indicates that the road dust in this area was highly polluted with PBDEs. BDE-209 was the predominated congener in the study dusts, indicating that the commercial

Table 3 Hazard quotient for polybrominated diphenyl ether (PBDE) and metals in the road dust from the waste plastic recycling area

\begin{tabular}{|c|c|c|c|c|c|c|}
\hline & \multicolumn{3}{|l|}{ Adults } & \multicolumn{3}{|l|}{ Children } \\
\hline & 5th percentile & Median & 95th percentile & 5th percentile & Median & 95th percentile \\
\hline As & $5.60 \mathrm{E}-02$ & $8.90 \mathrm{E}-02$ & $1.18 \mathrm{E}-01$ & $3.86 \mathrm{E}-01$ & $6.13 \mathrm{E}-01$ & $8.08 \mathrm{E}-01$ \\
\hline $\mathrm{Cd}$ & $3.10 \mathrm{E}-02$ & $6.80 \mathrm{E}-02$ & 4.82E-01 & $1.61 \mathrm{E}-01$ & $3.54 \mathrm{E}-01$ & $2.50 \mathrm{E}+00$ \\
\hline $\mathrm{Cr}$ & 4.10E-02 & $5.90 \mathrm{E}-02$ & $8.60 \mathrm{E}-02$ & $3.22 \mathrm{E}-01$ & 4.65E-01 & $6.84 \mathrm{E}-01$ \\
\hline $\mathrm{Cu}$ & $4.00 \mathrm{E}-03$ & $5.00 \mathrm{E}-03$ & 4.30E-02 & $2.00 \mathrm{E}-02$ & $3.20 \mathrm{E}-02$ & $2.54 \mathrm{E}-01$ \\
\hline $\mathrm{Hg}$ & $1.00 \mathrm{E}-03$ & $4.00 \mathrm{E}-03$ & $3.30 \mathrm{E}-02$ & $6.00 \mathrm{E}-03$ & $2.30 \mathrm{E}-02$ & $1.91 \mathrm{E}-01$ \\
\hline $\mathrm{Pb}$ & $1.40 \mathrm{E}-02$ & $2.40 \mathrm{E}-02$ & $2.43 \mathrm{E}-01$ & $1.04 \mathrm{E}-01$ & $1.74 \mathrm{E}-01$ & $1.77 \mathrm{E}+00$ \\
\hline $\mathrm{Sb}$ & $2.60 \mathrm{E}-02$ & $5.30 \mathrm{E}-02$ & $2.03 \mathrm{E}+00$ & $1.49 \mathrm{E}-01$ & $3.04 \mathrm{E}-01$ & $1.15 \mathrm{E}+01$ \\
\hline $\mathrm{Zn}$ & $1.00 \mathrm{E}-03$ & $1.00 \mathrm{E}-03$ & $1.00 \mathrm{E}-02$ & $5.00 \mathrm{E}-03$ & $7.00 \mathrm{E}-03$ & $6.50 \mathrm{E}-02$ \\
\hline Metals $^{\mathrm{a}}$ & $2.14 \mathrm{E}-01$ & $3.19 \mathrm{E}-01$ & $2.60 \mathrm{E}+00$ & $1.43 \mathrm{E}+00$ & $2.06 \mathrm{E}+00$ & $1.50 \mathrm{E}+01$ \\
\hline BDE-47 & $6.20 \mathrm{E}-08$ & $3.82 \mathrm{E}-05$ & 7.93E-04 & $3.38 \mathrm{E}-07$ & $2.08 \mathrm{E}-04$ & 4.32E-03 \\
\hline BDE-99 & $1.71 \mathrm{E}-07$ & $3.86 \mathrm{E}-05$ & $1.02 \mathrm{E}-03$ & $9.28 \mathrm{E}-07$ & $2.10 \mathrm{E}-04$ & $5.54 \mathrm{E}-03$ \\
\hline BDE-153 & $8.56 \mathrm{E}-08$ & $5.13 \mathrm{E}-05$ & $3.52 \mathrm{E}-03$ & 4.64E-07 & $2.79 \mathrm{E}-04$ & $1.92 \mathrm{E}-02$ \\
\hline BDE-209 & $3.24 \mathrm{E}-05$ & 4.93E-03 & $8.28 \mathrm{E}-02$ & $2.41 \mathrm{E}-04$ & $3.66 \mathrm{E}-02$ & $6.16 \mathrm{E}-01$ \\
\hline Penta-BDE & $2.71 \mathrm{E}-08$ & $3.74 \mathrm{E}-06$ & $6.11 \mathrm{E}-05$ & $1.48 \mathrm{E}-07$ & $2.04 \mathrm{E}-05$ & $3.32 \mathrm{E}-04$ \\
\hline Octa-BDE & $5.95 \mathrm{E}-07$ & $3.67 \mathrm{E}-05$ & $1.15 \mathrm{E}-03$ & $3.59 \mathrm{E}-06$ & $2.21 \mathrm{E}-04$ & $6.96 \mathrm{E}-03$ \\
\hline PBDEs $^{\mathrm{b}}$ & 4.34E-05 & $5.77 \mathrm{E}-03$ & $8.29 \mathrm{E}-02$ & $3.11 \mathrm{E}-04$ & $4.03 \mathrm{E}-02$ & $6.17 \mathrm{E}-01$ \\
\hline
\end{tabular}

${ }^{\text {a }}$ Sum of the eight metals

${ }^{\mathrm{b}}$ Sum of BDE-47, BDE-99, BDE-153, and BDE-209 
deca-BDE product was dominant. The road dusts have suffered from moderate to high metal pollution and in particular, high $\mathrm{Cd}, \mathrm{Hg}$, and $\mathrm{Sb}$ pollution. Source assessment indicated that $\mathrm{Cd}, \mathrm{Cu}, \mathrm{Sb}, \mathrm{Zn}$, and $\mathrm{Cr}$ in dusts were mainly derived from inputs from poorly controlled plastic recycling operations in this area. Although the health risk from exposure to dust PBDEs was low, the noncarcinogenic risks for certain metals in this dust to local children exceeded an acceptable level. Further research on risk assessments and control measures for harmful chemicals arising from mechanical recycling of plastic wastes is warranted.

Acknowledgments This research was supported by the National Environmental Protection Public Welfare Science and Technology Research Program of China (201309023), and the Fundamental Research Funds for the Central Universities (2015MS60).

\section{References}

Al-Salem SM, Lettieri P, Baeyens J (2009) Recycling and recovery routes of plastic solid waste (PSW): a review. Waste Manag 29:2625-2643. doi:10.1016/j.wasman.2009.06.004

Behnisch PA, Hosoe K, Sakai S (2003) Brominated dioxin-like compounds: in vitro assessment in comparison to classical dioxin-like compounds and other polyaromatic compounds. Environ Int 29: 861-877. doi:10.1016/S0160-4120(03)00105-3

Besis A, Samara C (2012) Polybrominated diphenyl ethers (PBDEs) in the indoor and outdoor environments-A review on occurrence and human exposure. Environ Pollut 169:217-229. doi:10.1016/j. envpol.2012.04.009

Cao Z, Xu F, Covaci A, Wu M, Wang H, Yu G, Wang B, Deng S, Huang J, Wang X (2014) Distribution patterns of brominated, chlorinated, and phosphorus flame retardants with particle size in indoor and outdoor dust and implications for human exposure. Environ Sci Technol 48:8839-8846. doi:10.1021/es501224b

CEPA (Chinese Environmental Protection Administration) (1995) Environmental quality standard for soils (GB15618-1995). CEPA, Beijing (in Chinese)

Charlesworth S, De Miguel E, Ordóñez A (2011) A review of the distribution of particulate trace elements in urban terrestrial environments and its application to considerations of risk. Environ Geochem Health 33:103-123. doi:10.1007/s10653-010-9325-7

Chen SJ, Ma YJ, Wang J, Chen D, Luo XJ, Mai BX (2009) Brominated flame retardants in children's toys: concentration, composition, and children's exposure and risk assessment. Environ Sci Technol 43: 4200-4206. doi:10.1021/es9004834

Chen X, Xia X, Zhao Y, Zhang P (2010) Heavy metal concentrations in roadside soils and correlation with urban traffic in Beijing, China. $\mathrm{J}$ Hazard Mater 181:640-646. doi:10.1016/j.jhazmat.2010.05.060

Chen Y, Li J, Liu L, Zhao N (2012) Polybrominated diphenyl ethers fate in China: a review with an emphasis on environmental contamination levels, human exposure and regulation. J Environ Manage 113: 22-30. doi:10.1016/j.jenvman.2012.08.003

Cheng HF, Hu YA (2010) Lead $(\mathrm{Pb})$ isotopic fingerprinting and its applications in lead pollution studies in China: a review. Environ Pollut 158:1134-1146. doi:10.1016/j.envpol.2009.12.028

Cheng X, Shi H, Adams CD, Ma Y (2010) Assessment of metal contaminations leaching out from recycling plastic bottles upon treatments. Environ Sci Pollut Res 17:1323-1330. doi:10.1007/s11356-0100312-4
CNEMC (China National Environmental Monitoring Center) (1990) The soil background value in China. China Environmental Science Press, Beijing (in Chinese)

CSB (China Statistics Bureau) (2012) China statistical yearbook 2012. China Statistics Press, Beijing (in Chinese)

Dixon SL, Gaitens JM, Jacobs DE, Strauss W, Nagaraja J, Pivetz T, Wilson JW, Ashley PJ (2009) Exposure of U.S. children to residential dust lead, 1999-2004: II. The contribution of lead-contaminated dust to children's blood lead levels. Environ Health Perspect 117: 468-674. doi:10.1289/ehp.11918

EFSA (European Food Safety Authority) (2010) Management of leftcensored data in dietary exposure assessment of chemical substances. EFSA J 8(3):1557

Eguchi A, Isobe T, Ramu K, Tue NM, Sudaryanto A, Devanathan G, Viet PH, Tana RS, Takahashi S, Subramanian A, Tanabe S (2013) Soil contamination by brominated flame retardants in open waste dumping sites in Asian developing countries. Chemosphere 90:23652371. doi:10.1016/j.chemosphere.2012.10.027

Faure F, Saini C, Potter G, Galgani F, de Alencastro LF, Hagmann P (2015) An evaluation of surface micro- and mesoplastic pollution in pelagic ecosystems of the Western Mediterranean Sea. Environ Sci Pollut Res 22:12190-12197. doi:10.1007/s11356015-4453-3

Guney M, Zagury GJ (2012) Heavy metals in toys and low-cost jewelry: critical review of U.S. and Canadian legislations and recommendations for testing. Environ Sci Technol 46:4265-4274. doi:10.1021/ es203470x

He Z, Li G, Chen J, Huang Y, An T, Zhang C (2015) Pollution characteristics and health risk assessment of volatile organic compounds emitted from different plastic solid waste recycling workshops. Environ Int 77:85-94. doi:10.1016/j.envint.2015.01.004

Huang D-Y, Zhou S-G, Hong W, Feng W-F, Tao L (2013) Pollution characteristics of volatile organic compounds, polycyclic aromatic hydrocarbons and phthalate esters emitted from plastic wastes recycling granulation plants in Xingtan Town, South China. Atmos Environ 71:327-334. doi:10.1016/j.atmosenv.2013.02.011

Jambeck JR, Geyer R, Wilcox C, Siegler TR, Perryman M, Andrady A, Narayan R, Law KL (2015) Marine pollution. Plastic waste inputs from land into the ocean. Science 347:768-771. doi:10.1126/ science. 1260352

Jiang H, Lin Z, Wu Y, Chen X, Hu Y, Li Y, Huang C, Dong Q (2014) Daily intake of polybrominated diphenyl ethers via dust and diet from an e-waste recycling area in China. J Hazard Mater 276:3542. doi:10.1016/j.jhazmat.2014.05.014

Kajiwara N, Noma Y, Takigami H (2008) Photolysis studies of technical decabromodiphenyl ether (DecaBDE) and ethane (DeBDethane) in plastics under natural sunlight. Environ Sci Technol 42:4404-4409. doi:10.1021/es800060j

Kotori P, Beqiraj A, Cullap A, Beqiraj E (2012) Distribution of mercury in contaminated zones and rehabilitation of the PVC hot spot in Vlora. J Environ Prot Ecol 13:86-95

La Guardia MJ, Hale RC, Harvey E (2006) Detailed polybrominated diphenyl ether (PBDE) congener composition of the widely used penta-, octa-, and deca-PBDE technical flame-retardant mixtures. Environ Sci Technol 40:6247-6254. doi:10.1021/es060630m

La Guardia MJ, Hale RC, Harvey E (2007) Evidence of debromination of decabromodiphenyl ether (BDE-209) in biota from a wastewater receiving stream. Environ Sci Technol 41:6663-6670. doi:10. $1021 / \mathrm{es} 070728 \mathrm{~g}$

Labunska I, Harrad S, Santillo D, Johnston P, Yun L (2013) Domestic duck eggs: an important pathway of human exposure to PBDEs around e-waste and scrap metal processing areas in Eastern China. Environ Sci Technol 47:9258-9266. doi:10.1021/es402300m

Lazarevic D, Aoustin E, Buclet N, Brandt N (2010) Plastic waste management in the context of a European recycling society: comparing 
results and uncertainties in a life cycle perspective. Resour Conserv Recycl 55:246-259. doi:10.1016/j.resconrec.2010.09.014

Lei L, Chen Y, Li Z, Li C (2012) Heavy metal ingredient analysis in the dust of the Chinese urban areas. J Saf Environ 12:124-129 (in Chinese)

Leung AO, Luksemburg WJ, Wong AS, Wong MH (2007) Spatial distribution of polybrominated diphenyl ethers and polychlorinated dibenzo-p-dioxins and dibenzofurans in soil and combusted residue at Guiyu, an electronic waste recycling site in southeast China. Environ Sci Technol 41:2730-2737. doi:10.1021/es0625935

Leung AO, Duzgoren-Aydin NS, Cheung KC, Wong MH (2008) Heavy metals concentrations of surface dust from e-waste recycling and its human health implications in southeast China. Environ Sci Technol 42:2674-2680. doi:10.1021/es071873x

Leung AO, Zheng J, Yu CK, Liu WK, Wong CK, Cai Z, Wong MH (2011) Polybrominated diphenyl ethers and polychlorinated dibenzo-p-dioxins and dibenzofurans in surface dust at an E-waste processing site in Southeast China. Environ Sci Technol 45:5775 5782. doi:10.1021/es103915w

Li J, Duan H, Shi P (2011) Heavy metal contamination of surface soil in electronic waste dismantling area: site investigation and sourceapportionment analysis. Waste Manag Res 29:727-738. doi:10. 1177/0734242X10397580

Liu HL (2011) Wen'an: when will the confusion leading to "pointless exposure" end? The situation in the Wen'an waste plastics industry after public concern. Environ Conserv (China) Z1:77-80 (in Chinese)

Liu R, Ma W, Zhang W (2001) Land chronicle of Wen'an. China Land Press, Beijing, ISBN: 7-80097-411-1 (in Chinese)

Lu X, Zhang X, Li LY, Chen H (2014) Assessment of metals pollution and health risk in dust from nursery schools in Xi'an, China. Environ Res 128:27-34. doi:10.1016/j.envres.2013.11.007

Lyu R, Huang Q, Yang Y, Tang Z, Tian S, He J, Liu F (2015) Distributions and risks of polybrominated diphenyl ethers in daily plastic products. Res Environ Sci 28:74-81. doi:10.13198/j.issn. 1001-6929.2015.01.10, in Chinese

Ma TT, Wu LH, Chen L, Zhang HB, Teng Y, Luo YM (2015) Phthalate esters contamination in soils and vegetables of plastic film greenhouses of suburb Nanjing, China and the potential human health risk. Environ Sci Pollut Res 22:12018-12028. doi:10.1007/ s11356-015-4401-2

Morf LS, Tremp J, Gloor R, Huber Y, Stengele M, Zennegg M (2005) Brominated flame retardants in waste electrical and electronic equipment: substance flows in a recycling plant. Environ Sci Technol 39: 8691-8699. doi:10.1021/es051170k

Morf LS, Tremp J, Gloor R, Schuppisser F, Stengele M, Taverna R (2007) Metals, non-metals and PCB in electrical and electronic waste-actual levels in Switzerland. Waste Manag 27:1306-1316. doi:10.1016/j. wasman.2006.06.014

Muller G (1969) Index of geoaccumulation in sediments of the Rhine River. GeoJournal 2:108-118

Ni K, Lu Y, Wang T, Kannan K, Gosens J, Xu L, Li Q, Wang L, Liu S (2013) A review of human exposure to polybrominated diphenyl ethers (PBDEs) in China. Int J Hyg Environ Health 216:607-623. doi:10.1016/j.ijheh.2013.02.002

Nose KS, Hashimotom SJ, Takahashi S, Noma YK, Sakai SI (2007) Degradation pathways of decabromodiphenyl ether during hydrothermal treatment. Chemosphere 68:120-125. doi:10.1016/j. chemosphere.2006.12.030

Pacheco EBAV, Ronchetti LM, Masanet E (2012) An overview of plastic recycling in Rio de Janeiro. Resour Conserv Recycl 60:140-146. doi:10.1016/j.resconrec.2011.12.010

Rochman CM, Browne MA, Halpern BS, Hentschel BT, Hoh E, Karapanagioti HK, Rios-Mendoza LM, Takada H, Teh S, Thompson RC (2013) Policy: classify plastic waste as hazardous. Nature 494:169-171. doi:10.1038/494169a
Santos MC, Nóbrega JA, Cadore S (2011) Determination of Cd, Cr, Hg and $\mathrm{Pb}$ in plastics from waste electrical and electronic equipment by inductively coupled plasma mass spectrometry with collisionreaction interface technology. J Hazard Mater 190:833-839. doi: 10.1016/j.jhazmat.2011.04.004

Shi S, Dong L, Yang W, Zhou L, Zhang L, Zhang X, Huang Y (2014) Monitoring of airborne polybrominated diphenyl ethers in the urban area by means of road dust and camphor tree barks. Aerosol Air Qual Res 14:1106-1113. doi:10.4209/aaqr.2012.11.0304

Soares EP, Saiki M, Wiebeck H (2005) Determination of inorganic constituents and polymers in metallized plastic materials. J Radioanal Nucl Chem 264:9-13. doi:10.1007/s10967-005-0667-Z

Sun R-G, Li L-X, Cheng X-J, Tian K-J, Li X-Q (2014) Analysis of distribution and key hydrochemistry of high-fluoride groundwater in Wen'an city. J Chin Inst Water Res Hydropower Res 12:316-322 (in Chinese)

Tang R, Ma K, Zhang Y, Mao Q (2013) The spatial characteristics and pollution levels of metals in urban street dust of Beijing, China. Appl Geochem 35:88-98. doi:10.1016/j.apgeochem.2013.03.016

Tang Z, Huang Q, Cheng J, Yang Y, Yang J, Guo W, Nie Z, Zeng N, Jin L (2014) Polybrominated diphenyl ethers in soils, sediments, and human hair in a plastic waste recycling area: a neglected heavily polluted area. Environ Sci Technol 48:1508-1516. doi:10.1021/ es404905u

Tang Z, Zhang L, Huang Q, Yang Y, Nie Z, Cheng J, Yang J, Wang Y, Chai M (2015) Contamination and risk of heavy metals in soils and sediments from a typical plastic waste recycling area in north China. Ecotoxicol Environ Saf, in press. doi:10.1016/j.ecoenv.2015.08.006

Thompson RC, Moore CJ, vom Saal FS, Swan SH (2009) Plastics, the environment and human health: current consensus and future trends. Philos Trans R Soc Lond B Biol Sci 364:2153-2166. doi:10.1098/ rstb.2009.0053

USEPA (1989) Risk assessment guidance for superfund. Human health evaluation manual (Part A) vol. 1. Office of Emergency and Remedial Response, US Environmental Protection Agency, Washington, DC

USEPA (2001) Child-specific exposure factors handbook. EPA-600-P00-002B. National Center for Environmental Assessment, Office of Research and Development, US Environmental Protection Agency, Washington, DC

Wang J, Chen SJ, Tian M, Ma YJ, Luo XJ, Mai BX (2010) Polybrominated diphenyl ethers (PBDEs) in indoor and outdoor dust from an electronic waste (e-waste) recycling area in South China: contamination and human exposure. Environ Sci 31:173178 (in Chinese)

Watkins DJ, McClean MD, Fraser AJ, Weinberg J, Stapleton HM, Sjödin A, Webster TF (2011) Exposure to PBDEs in the office environment: evaluating the relationships between dust, handwipes, and serum. Environ Health Perspect 119:1247-1452. doi:10.1289/ehp. 1003271

Wei B, Yang L (2010) A review of heavy metal contaminations in urban soils, urban road dusts and agricultural soils from China. Microchem J 94:99-107. doi:10.1016/j.microc.2009.09.014

Wu MH, Pei JC, Zheng M, Tang L, Bao YY, Xu BT, Sun R, Sun YF, Xu G, Lei JQ (2015) Polybrominated diphenyl ethers (PBDEs) in soil and outdoor dust from a multi-functional area of Shanghai: levels, compositional profiles and interrelationships. Chemosphere 118:8795. doi:10.1016/j.chemosphere.2014.06.022

Xu GF, Li GJ, Fan L (2010) Solid waste management based on circular economy theory: a case study in Wen'an, Heibei Province. Environ Sci Technol (China) 33:506-508 (in Chinese)

Xu F, Liu Y, Wang J, Zhang G, Zhang W, Liu L, Wang J, Pan B, Lin K (2015) Characterization of heavy metals and brominated flame retardants in the indoor and outdoor dust of e-waste workshops: implication for on-site human exposure. Environ Sci Pollut Res 22: 5469-5480. doi:10.1007/s11356-014-3773-Z 
Yang J, Buekens A (2014) Recycling of WEEE plastics: a review. J Mater Cycles Waste Manag 16:415-434. doi:10.1007/ s10163-014-0241-2

Yang Z, Wang Y, Shen Z, Niu J, Tang Z (2009) Distribution and speciation of heavy metals in sediments from the mainstream, tributaries, and lakes of the Yangtze River catchment of Wuhan, China. J Hazard Mat 166:1186-1194. doi:10.1016/j.jhazmat.2008.12.034

Yu Y-X, Pang Y-P, Li C, Li J-L, Zhang X-Y, Yu Z-Q, Feng J-L, Wu M-H, Sheng G-Y, Fu J-M (2012) Concentrations and seasonal variations of polybrominated diphenyl ethers (PBDEs) in- and out-house dust and human daily intake via dust ingestion corrected with bioaccessibility of PBDEs. Environ Int 42:124-131. doi:10.1016/j.envint. 2011.05.012

Zheng X, Xu F, Chen K, Zeng Y, Luo X, Chen S, Mai B, Covaci A (2015) Flame retardants and organochlorines in indoor dust from several ewaste recycling sites in South China: composition variations and implications for human exposure. Environ Int 78:1-7. doi:10. 1016/j.envint.2015.02.006 